other things, reminds us that the true poet is skilled in the "Art of Numbers" and uses them as a poetic "maske" under which he hides "the misteries of his doctrine." The technical aspects of verse make it possible for the poet to deliver his message "darkely." Milton, imitating Orpheus and also Christ, devises a complicated rhyme scheme in order to symbolize the difficult order achieved by the end of Lycidas and in order to assert his belief, everywhere implied, that the poet "raiseth beauty even out of deformity, order and regularity out of Chaos and confusion."7

JOSEPH ANTHONY WITTREICH, JR.

University of Wisconsin

Notes

${ }^{1}$ I quote from Denise Levertov, "Some Notes on Organic Form," Poetry, 106 (1965), 422. The entire essay, but especially the paragraph from which this quotation is taken, pertains to my discussion of Lycidas.

2 Joseph H. Summers comments importantly: see George Herbert: His Religion and Art (London: Chatto and Windus, 1954), pp. 90-92.

${ }^{3}$ New Memoirs of the Life and Poetical Works of Mr. John Milton (London, 1740), p. 32.

"E. K., "[The Epistle Dedicatory to The Shepheards Calender]," in Elizabethan Critical Essays, ed. G. Gregory Smith (Oxford: Clarendon, 1904), 1, 128.

5 The first quotation is from Samuel Daniel, $A$ Defence of Rhyme, in Elizabethan Critical Essays, II, 366; the second from George Puttenham, The Arte of English Poesie (1589; rpt. London: R. Triphook, 1811), p. 73.

- Puttenham, pp. 68, 71-72.

${ }^{7}$ Henry Reynolds, Mythomystes, in Critical Essays of the Seventeenth Century, ed. J. E. Spingarn, I (Oxford: Clarendon Press, 1908-09), 156, 159, 172; and Edward Phillips, "Preface to Theatrum Poetarum," in the same work, iI, 257. Also pertinent are Milton's comments on "crypsis of method" in Artis Logicae (Columbia Milton, XI, 485) and on Christ's use of the method in The Doctrine and Discipline of Divorce (Yale Milton, II, 308, also pp. 310, 338.)

In my formal response to Professor Low's rejoinder, I have focused on our different comprehensions of Milton's poem; but I do not wish to conclude this exchange without directing attention to Low's claim that "rhyme in a long poem is bound to repeat itself, since there are only so many convenient rhyme sounds in English." Such a claim greatly underestimates the rhyme potential of the English language, and this point the first 193 lines of Paradise Lost illustrate. Working out a rhyme scheme for those lines in the same way that I worked out one for Lycidas, I find in lines 1-100 thirteen rhymes that involve only twenty-six of those lines (seventy-four lines are unrhymed). In the next ninety-three lines there is a good deal of "random repetition"; but despite it there are in 11. 1-193 roughly seven times the number of unrhymed lines that Low finds in Lycidas (he accepts, I assume, the commonplace notion that there are ten unrhymed lines in the poem). I can only conclude that if Milton was truly concerned with "avoiding repetitions" in Lycidas he could have done so as easily here as he does in Paradise Lost. Furthermore, this conclusion is encouraged by the revisions in the Trinity MS, which reveal a desire to perfect the poem's rhyme. The substitutions of lament, sent, and shore (11. 60, 62, 63) for son, bee, and lee are especially significant; so is the deletion of "fam'd" from line 85 , which allows the line to end with "flood." Had Milton not made this last substitution, he would have had in "fam'd" a word that has no rhyme in Lycidas (a curious deletion if we accept Low's hypothesis that, to the extent that his rhyme-impoverished language allows, Milton deliberately eschews rhyme in Lycidas). Note, too, the substitution of $u s e$ for $d o$ at the end of 1.67 and the insertion of "in the blest kingdoms of Joy, and Love" after 1. 176 in both the British Museum and Cambridge Univ. copies of Lycidas. See John Milton's Complete Poetical Works, ed. Harris Francis Fletcher, I (Urbana: Univ. of Illinois Press, 1943), 349, 352, 437, 439.

\section{Kipps and the Masterman Episode}

\section{To the Editor:}

In the recent article on H. G. Wells's Kipps, three of Harris Wilson's conclusions are debatable and a fourth may be supplemented. ${ }^{1}$ First, he states that the unexpected success of Chitterlow's play is a "serious structural flaw" in the novel, that it is "unconvincing and gratuitous as well, since Kipps has no real need of the money which the play brings him" (p. 68). However, it should be noted that the success of Chitterlow's play is the last in a series of chance events that influences Kipps's life and structures the novel. The series makes his life a pattern of "ups and downs." And all the events come to him "gratuitously" - that is, whether he "needs" them or not (the disastrous events, or "downs," he certainly does not need). They are gratuitous because their purpose is to show that chance, rather than determinism, is the predominant pattern in his life. ${ }^{2}$ To judge the success of Chitterlow's play unnecessary is to overlook this purpose in the events and to assume that their only purpose is to lead to a happy ending wherein Kipps is provided with just enough money to insure his happiness.

Second, Wilson concludes that Wells's reason for repressing the episode of Masterman's visit and death may have been commercial: Wells may have been afraid that the ideas of Masterman, an avowed socialist, would alienate conventional readers and diminish the sales of the novel. This may be true of Masterman's socialist-utopian ideas about establishing a better society; but if it were true of his criticism of the existing society, Wells would also have repressed Masterman's earlier social criticism (in Book II, Ch. vii, Sec. 4), especially since it is more strongly denunciatory there than in the repressed episode.

Admittedly, Wells did counteract that earlier criticism by showing, in the following section, Kipps's 
doubts about it and, in II:ix:1, even Masterman's doubts about it-as well as his unexpected expression of hope. But if Wells felt that Masterman's earlier criticism was safe to include because it was doubted afterwards, then he would have felt the same about the later criticism if it too was doubted afterwards. He would have included the first two excerpts which Professor Wilson quotes, followed by an ending like the last excerpt, in which Kipps and Ann disavow Masterman's ideas.

Third, Wilson implies an esthetic reason as well for Wells's repression of the later Masterman episode: it was an illustration of Wells's second conception of Kipps - "the complete study of a life in relation to England's social condition"-and he had discarded this conception because it would not have been compatible with his original conception of the novel as "comic pathos." However, there is nothing in either of Wells's conceptions that would make the one inherently incompatible with the other. And indeed Wells has made the two compatible in Kipps. Not only is comic pathos obvious throughout, but the relation of Kipps's life to England's social condition is also pervasive and demonstrable. ${ }^{3}$ Repression of the later Masterman episode did not weaken this relation in the novel, nor would repression of his earlier social criticism have done so-nor would even the complete elimination of Masterman. The relation is part of the basic structure of the novel and therefore is independent of Masterman (though it utilizes him). Even twenty years after, Wells still described the novel in terms of his second conception: Kipps was one of his fictional characters who were "thwarted and crippled by the defects of our contemporary civilisation."

Happily, Wilson also concludes that Wells may have had another esthetic reason for repressing the episode: Masterman's ideas, requiring a "long, socialist-utopian digression," and "the effects of Masterman's ideas on Kipps" would not have been in keeping with the comic pathos of the novel. Four other esthetic reasons are also possible. First, elimination of a visit that ends in Masterman's death allows the novel to end on a note of hope in regard to him, just as it ends in regard to Kipps and Ann. After the scene in which Masterman raises a toast to "Hope of Life," Kipps plans to invite him to the seashore for his health: "Sea air might be the saving of 'im." Masterman is not mentioned again in the novel, and so readers are allowed to suppose that, critical as his illness seems, he may yet live for a long while. Nor is the note of hope spoiled by Kipps's subsequent money loss (which would make his invitation to Masterman impossible), for Kipps immediately becomes financially capable again.

Another reason lies in the wording of Wilson's question. He had asked, "Why ... did Wells eventually decide to dispense with Masterman's final appearance, leaving the strong social criticism in Kipps largely implicit?" (p. 68). An answer is, to make the strong social criticism largely implicit. For example, Masterman's later social criticism, which comprises the first two quoted excerpts, focuses upon the "stupidity" ("foolishness," "silliness") of people in the existing imperfect society, and it is this idea alone which, as the seventh excerpt shows, Kipps accepts. However, instead of including Masterman's and then Kipps's expression of the idea in the published novel, Wells shows the idea implicitly in III:ii:4. There all the social influences upon Kipps are represented by the monster Stupidity and shown to be the cause of his unhappiness. In other words, Wells made social criticism implicit by means of his second conceptionby making the novel a study of Kipps's life in relation to England's social condition.

Another reason why Wells repressed Masterman's socialist-utopian ideas may be that they extended beyond social criticism, either implicit or explicit, and constituted a proposal for establishing a better society. While finishing the novel, Wells was also writing $A$ Modern Utopia and may have realized that such ideas were more suitable to this work than to the other. Accordingly, socialist-utopian ideas became part of A Modern Utopia but not part of Kipps.

It may seem that at least the fraction of Masterman's criticism which Kipps absorbed (the sixth and seventh excerpts) could have been separated from the rest of the episode and retained. However, even then, besides being out of keeping with the comic pathos, the retained fraction would have shown Kipps's growing awareness of England's social condition and not merely the relation of his life to that condition. Throughout the novel, unawareness is characteristic of Kipps in most respects, ${ }^{5}$ and his mentality, even his character, would have seemed to change drastically if, at the end of the novel, he had suddenly understood and judged part of Masterman's criticism. Consequently, Wells left Kipps almost totally unaware of the relation of his life to the social condition. Years later, referring to that condition as change, Wells described Kipps as one of his fictional characters who was "change-driven and unable to understand." 6

In writing the episode, Wells showed that he was inclined "to reconcile narrative and ideology" (p. 69); but in repressing it, he showed that he was not going to attempt this reconciliation in Kipps, as he was to attempt it in later works. Instead, he tried in Kipps to reconcile social criticism and narrative, and, by making the one implicit in the other, he succeeded.

KenNeth B. Newell

Virginia Commonwealth University 


\section{Notes}

1 "The Death of Masterman: A Repressed Episode in H. G. Wells's Kipps," PMLA, 86(1971), 63-69.

${ }^{2}$ For a fuller discussion of this pattern in Kipps, see my Structure in Four Novels by H. G. Wells (The Hague and Paris: Mouton, 1968), pp. 42, 54-56, 62, and 68-70.

${ }^{3}$ Structure, pp. 42-50 and 61-66.

4 Preface to Vol. vII (1925) of The Works of H. G. Wells, Atlantic Ed. (London: T. Fisher Unwin, 1924-27), p. ix.

${ }^{5}$ See especially II:ix:2 and the final section of the novel. Structure, pp. 62-64 and 70-71.

6 "A General Introduction to the Atlantic Edition," in Works, I (1924), xvii.

\section{E. M. Forster and George Meredith}

In her very useful study of the manuscripts of $A$ Passage to India (PMLA, 85, 1970, 284-94) June Perry Levine quotes the following passage from MS. B describing Fielding's reaction to a Marabar Cave:

"Have you anything to say?" [he asks the cave] "Boum." "Of man's first disobedience and the sin / Of that forbidden tree ..." he remarked. Then he recited, in a different tone of voice, the beginning of a poem that he had once admired even more than Paradise Lost because it was adventurous and sane, and sang of the triumphs as well as the fall of man

Enter these enchanted woods

You who dare

A shout, a whistle, a whisper, all were "Boum," loud or soft but without distinction in quality. ${ }^{1}$

(The passage goes on to describe how the same result occurs when Fielding recites the Persian quatrain that Aziz in the final version of the novel intends to have on his tomb.) Professor Levine suggests that Fielding is futilely quoting Milton and Dante in the cave. But the poem that Fielding once admired more than Paradise Lost because it sang of man's triumph as well as his fall is not The Divine Comedy but George Meredith's once well-known "The Woods of Westermain." The lines quoted by Fielding open the poem and make up the refrain at the end of each stanza. To mistake Meredith for Dante even in the manuscripts of $A$ Passage of India is to miss a dimension of irony in the portrait of Fielding that remains in the final version of the novel.

Forster quoted from Meredith's poetry at least once before in his fiction without identifying it. While discussing how Leonard Bast avoided "the anodyne of muddledom" in Howards End (1910) Forster quoted from Modern Love,

And if I drink oblivion of a day, So shorten I the stature of my soul. ${ }^{2}$

Forster went on to comment, "It is a hard saying, and a hard man wrote it, but it lies at the foot of all character." 3 When Forster came to write A Passage to
India, however, Meredith appears to have gone soft for him. Forster's changed opinion can be seen three years after the publication of $A$ Passage to India in Aspects of the Novel (1927):

Meredith is not the great name he was twenty or thirty years ago, when much of the universe and all of Cambridge trembled.... Though fashion will turn and raise him a bit, he will never be the spiritual power he was about the year 1900 . His philosophy has not worn well. ${ }^{4}$

Forster's fellow Apostle, G. M. Trevelyan, has probably summarized best Cambridge's trembling admiration of Meredith in his 1906 study, The Poetry and Philosophy of George Meredith. In "The Woods of Westermain," according to Trevelyan, Meredith

chooses a forest to stand allegorically for human life,- a haunted forest, beautiful and homely to those who have no fear, but madly terrible to those who "quaver at a dread of dark." As the piece goes on, it becomes a book of ethical proverbs, a poetical Pilgrim's Script, a shower of characteristic percepts loosely held together by continual reference to the allegory of the woods, wherein lurks the enchantment for the lover of poetry. ${ }^{5}$

Trevelyan's opinion of the poem is not unlike Fielding's or even Forster's up to Howards End. "You must love the light so well," says Meredith in the poem, "That no darkness will seem fell,"6 and this, says Trevelyan, anticipating Forster's phrase in Howards End, "is a hard saying."?

Trevelyan does not cite the lines of "The Woods of Westermain" in which Meredith explains the necessary unity that allows one to dare the enchanted woods of life:
Each of each in sequent birth,
Blood and brain and spirit, three
(Say the deepest gnomes of Earth),
Join for true felicity.
Are they parted, then expect
Some one sailing will be wrecked.
Separate hunting are they sped,
Scan the morsel coveted.
Earth that Triad is: she hides
Joy from him who that divides;
Showers it when the three are one
Glassing her in union. ${ }^{8}$

These lines read ironically in the light of Fielding's experience in the Marabar Caves. There are no gnomes in that deep earth. The union of blood, brain, and spirit can produce no triadic joy in them. There is only the horrifying monistic vision: "Pathos, piety, courage - they exist, but are identical, and so is filth. Everything exists, nothing has value." 9

Meredith as well as Milton presumably had to be dropped when this vision becomes Mrs. Moore's rather than Fielding's. ${ }^{10}$ They are replaced, as Pro- 